\title{
ISLAMIC VALUES DALAM PENGAMBILAN KEPUTUSAN AKUNTANSI
}

\author{
Slamet Haryono \\ Universitas Islam Negeri Sunan Kalijaga \\ beningsilma@yaboo.com
}

\begin{abstract}
This research examines the influence of Islamic Values on the accounting judgement. Studies of religiosity are dominated by intrinsic and extrinsic religiosity approach. This study arranges religiosity instrument of Accounting and Auditing Standard for Islamic Financial Institutions. The of Islamic values in this study are derived trustworthiness, religious legitimacy, objectivity, professional competence and diligence, faith driven conduct, professional conduct and technical standards. The respondents were the employees of the Islamic financial institutions who has held accounting duties within the company. Data collection using the survey and used in data analysis total of 75 of 200 questionnaires distributed. The results showed that the religious legitimacy affect the accounting judgement significantly. Professional competence and diligence influence the accounting judgement significantly. Faith driven conduct and professional conduct and technical standards affect the accounting judgement significantly. However, found no evidence showed of the influence of trustworthiness and objectivity on the accounting judgement signicantly.
\end{abstract}

Keywords: Value, Islamic, Accounting, Judgement

\begin{abstract}
Abstrak
Tujuan penelitian ini adalah menguji pengaruh nilai-nilai Islam pada keputusan akuntansi. Nilai kegamaan dalam penelitian ini tidak menggunakan intrinsic religiousity indeks ataupun extrinsic religiousity scale seperti pada penelitian umumnya tetapi mengembangkan dari kode etik akuntan yang diterbitkan oleb Accounting and Auditing Standards for Islamic Finacial Istitutions. Tujuannya adalah supaya lebih sesuai untuk konteks akuntansi Islam. Nilai-nilai Islam meliputi trust worthiness, religius legitimay, objectivity, professional competence and diligence, faith driven conduct, professional conduct and technical standards. Responden penelitian adalah pegawai bagian akuntansi lembaga keuangan syariah di Daerah Istimewa Yogyakarta. Kuesioner yang kembali sebanyak 84 dari 200 kuesioner yang disebarkan dan data yang dapat diolah sebanyak 75 kuesioner. Hasil pengujian menunjukkan bahwa religious legitimacy, professional competence and diligence, faith driven conduct, professional conduct and technical standards berpengaruh secara signifikan terhadap keputusan akuntansi. Namun variabel trustworthiness, dan objectivity tidak mempengarubi secara signifikan terbadap keputusan akuntansi.
\end{abstract}

Kata Kunci: Nilai, Islam, Akuntansi, Keputusan

Permalink/DOI: http://dx.doi.org/10.18326/infs13.v10i1.69-92 


\section{Pendahuluan}

Manusia yang baik adalah manusia yang mampu mengimplematasikan sifat-sifat Tuhan di dunia nyata. Agama merupakan faktor yang paling mempengaruhi kebiasaan, nilai dan perilaku seseorang termasuk pegawai perusahaan dalam memilih pendekatan dan pengambilan keputusan. Bekerja merupakan kewajiban manusia untuk memenuhi kebutuhannya dan mencapai keseimbangan titik keseimbangan kehidupan individu dan sosial (Ali, 1988:577). Penelitian tentang nilai dan kepercayaan dapat menghasilkan wawasan mendalam bahwa pekerjaan merupakan bagian tidak terpisahkan dari aktivitas kehidupan seseorang (Robertson et al., 2002:585).

Islam mengatur semua aspek kehidupan secara jelas, dan sistematis yang menekankan pada nilai dan implementasinya (Rafiki dan Kalsom, 2014:1). Agama mempegaruhi formasi attitude, pilihan dan tindakan seseorang (Rice dan Al-Mossawi, 2002: 2). Etika dalam Islam didefinisikan sebagai prinsip dan nilai yang baik yang bersumber pada Islam (Al-Aidaros et al., 2013:12). Adebayo dan Hasan, (2013: 63) menekankan bahwa kajian mendalam terkait nilai etika dalam pengelolaan perbankan Islam sangat penting.

Al-Quran diturunkan adalah sebagai kitab petunjuk yang meliputi bidang akidah, syariah dan akhlak. Akan tetapi di luar ketiga petunjuk tersebut, al-Quran memberikan motivasi dan inspirasi kepada umat Islam dalam berbagai bidang kehidupan. Allah SWT berfirman bahwa: Ia (al Quran) merupakan kitab suci yang tidak pernah tercampur dengan kebatilan dari mana pun dan tidak ada sesuatu pun yang diragukan dari padanya (QS. Al-Baqarah :2). AlQuran sebagai kitab petunjuk yang membentuk kehidupan sosial dengan keseimbangan antara material dan spiritual sehingga alQuran menjadi jiwa dalam kehidupan seseorang.

Personal value tidak berdiri sendiri tetapi berkongruen dengan nilai-nilai yang lain seperti moral, agama, budaya dan teknologi. Nilai personalitas adalah keseimbangan beragam nilai-nilai intelektual, etika, emosi, fisik, dan agama. Globalisasi mempunyai berbagai manfaat seperti peningkatan pemahaman dan hubungan yang lebih erat, komunikasi antara masyarakat dan budaya, saling ketergantungan, dan harmoni. Agama mengandung 
banyak nilai-nilai kemanusian yang jika diikuti akan memberikan pedoman baik larangan dan apa-apa yang seharusnya dilakukan oleh manusia sehingga manusia akan mencapai kehidupan dunia dan akhirat yang baik.

Tetapi dunia berisi beragam kesempatan yang lengkap yang menyediakan pilihan bagi manusia untuk memilih berdasarkan keinginan dan lingkungan untuk bertindak secara baik ataupun buruk bagi dirinya dan sekaligus orang lain. Dalam jangka panjang sesungguhnya setiap tindakan baik yang hanya menguntungkan diri sendiri hanya sesaat karena tindakan yang merugikan tersebut akan tampak dan orang lain akan menganggap bahwa orang tersebut tadi tidak baik untuk diajak atau diberikan pekerjaan. Sesungguhnya orang yang melakukan tindakan merugikan orang lain akan kehilangan pekerjaan lainnya dan kehilangan manfaat dikemudian hari. Selain itu, seringkali orang yang dirugikan akan membalas jika ada kesempatan dan atau oleh orang lain.

Spiritualitas merupakan kekuatan penting dalam diri manusia yang dapat menginspirasi untuk menjadi manusia sepenuhnya. Spiritualitas memberikan manusia visi dan rasa dalam melihat kehidupan secara utuh dan mendorong kita untuk merenungkan masa lalu, sekarang dan masa depan. Oleh karena itu, spiritualitas mengacu pada perjalanan spiritual yang memiliki tiga arah: ke dalam diri, luar diri dan ke masa depan. Spritual mengatur hubungan dengan masyarakat dan alam secara keseluruhan. Spiritualitas menekankan kesatuan dan keterkaitan harmoni pribadi, sosial dan global. Pribadi yang memahami esensi spiritual berarti memiliki sumber daya batin cinta, keberanian dan harapan bukannya kebencian, ketakutan dan putus asa.

Profesionalisme diperlukan dalam segala bidang baik itu politik, bagian akuntansi, sosial dan budaya semakin meningkat. Nilai-nilai kepribadian seseorang menentukan tingkat profesionalisme dalam menggeluti pekerjaannya. Sama halnya dengan bidang - bidang lain, dibidang bagian akuntansi nilai-nilai kepribadian tersebut mempunyai peranan besar dalam kesuksesan pengambilan keputusan bagian akuntansi pegawai bagian akuntansi. Akuntan khususnya dan pegawai bagian akuntansi pada 
umumnya, menghadapi persaingan dari pegawai kerja asing dan domestik karena Indonesia adalah negara besar dengan potensi usaha yang juga besar. Pegawai bagian akuntansi Indonesia harus mengantisipasi dengan sedini mungkin. Persiapan tersebut meliputi hal-hal yang bersifat normatif dan juga etika serta mentalitas seorang profesional.

Disinilah pentingnya sumber daya manusia dari bidang bagian akuntansi khususnya akuntansi harus memiliki integritas moral dan etika berbasis nilai agama. Hal ini merupakan landasan yang sangat mendasar untuk membentuk seorang profesional berkualitas sehingga mampu bersaing, memiliki keunggulan kompetitif. Pegawai bagian akuntansi mempunyai peranan yang krusial bisa tercapai. pemenntah, pihak swasta, dan investor memerlukan informasi keuangan otentik untuk perencanaan, pengendalian pengeluaran, serta sebagai dasar penyusunan strategi bagian akuntansi. Fungsi pegawai bagian akuntansi sangat besar karena mewakili kepentingan masyarakat dalam rangka memberikan informasi yang berkulaitas tinggi. Semakin berdedikasi maka semakin tinggi kepercayaan masyarakat.

Faktor utama yang membentuk kepercayaan tersebut ialah perilaku pegawai bagian akuntansi dalam menjalankan pekerjaannya dan etika yang merupakan landasan bagi para karyawan bagian akuntansi untuk mengambil keputusan. Figur seorang aluntan sering kali dikaitkan dengan prilaku jujur, mempunyai integritas. mematuhi janji, dan dapat menjaga kerahasian. Reputasi yang baik diperoleh dari penilaian dan pandangan masyarakat. Oleh karena itu, untuk memenuhi harapan tersebut, karyawan bagian akuntansi yang harus mempunyai integritas, objektifitas, dan karakteristik kuat, sehingga perlu dibekali pendidikan etika. Pendidikan etika ini mencakup didalamnya pengembangan nilai-nilai kepribadian yaitu nilai moralitas sebagai penuntun kehidupan dan bekerja sebagai pegawai bagian akuntansi.

Pengembangan nilai-nilai Islam dalam lingkup individu berperan secara dominan dalam mempersiapkan sumber daya yang berkarakter kuat. Akuntan yang berkarakter kuat, biasanya akan sangat membantu menciptakan situasi kerja yang kondusif dan adanya 
saling menghargai. Oleh karena itu, tulisan ini bertujuan mengungkap nilai-nilai keislaman individu pegawai bagian akuntansi. Tulisan ini bertujuan untuk menjawab dua pokok masalah yaitu: pertama, bagaimana nilai-nilai keislaman individu (Islamic personal values) pegawai bagian akuntansi dalam keputusan-keputusan profesional yang diambilnya sebagai seorang pegawai bagian akuntansi. Kedua, bagaimana perbedaan Islamic personal values antara pegawai bagian akuntansi berlatar belakang pendidikan jurusan akuntansi dan nonakuntansi dari sisi gender yaitu pria dan wanita dalam keputusan-keputusan profesional yang diambilnya sebagai seorang pegawai bagian akuntansi. Berdasarkan pemaparan di atas, tulisan ini ingin menjawab permasalahan "bagaimana pengaruh nilai-nilai islam (Islamic values) dalam pengambilan keputusan akuntansi para pegawai akuntansi di lembaga lembaga keuangan syariah”.

\section{Nilai Keislaman (Islamic value)}

Religiositas adalah kualitas kehidupan seseorang dalam interaksinya dengan Tuhan, sesama manusia, dan alam semesta yang disertai keterikatan dan ketaatan manusia terhadap agama, untuk melaksanakan ajaran agama. Religius intrinsik adalah komitmen internal untuk terlibat langsung dalam agama dengan memikirkan secara mendalam dan melaksanakan yang diperintahkan agama serta menjadikan agama sebagai tujuan akhirnya. Religiositas ekstrinsik menganggap agama merupakan alat untuk mencapai tujuan-tujuan pribadinya.

Individu dengan tingkat religiositas intrinsik yang tinggi selalu berusaha menjaga kemurnian hati, memahami dan berkomitmen pada pelaksanaan agamanya sehingga agama memberikan kekuatan dan keyakinan diri, serta memberi arah menjalani hidup. Agama akan terinternalisasi dan merasuk dalam diri sehingga menjadi bagian dari kepribadiannya yang tercermin dalam pemikiran, ucapan, dan tindakannya. Instrumen religiositas intrinsik memiliki kemampuan menjelaskan perilaku seseorang (Nazaruddin, 2011). Abbas Ali (1988; 579-580) sudah menyusun 53 indikator, Rafiki \& Wahab (2014:1) mengelompokkan elemen agama menjadi dua kategori yaitu Individual Level yang terdiri dari Kreativitas (Creativity), kejujuran 
(bonesty) dan kepercayaan (trust), pencapaian diri (personal fulfillment), komitmen (commitment), motivasi (motivation) dan kepuasan kerja (job satisfaction), komitmen organisasional (organisational commitment) sedangkan organization level terdiri dari pengembangan emosional (emotional development), kompetensi spiritual (spiritual competence), encouraged bolistic ways of working, membangun komunitas (developed community at work), pemberdayaan (empowered the workforce and buman society), pencegahan risiko dan etika (risk aversion and ethics), pengelolaan batin dan pengembangan karir (stress management and career development). Dari penelitian terdahulu menunjukkan bahwa pegawai akuntansi lebih menaruh perhatian besar terhadap masalah etika, tetapi bukan berarti pegawai jurusan non akuntansi tidak perduli terhadap etika itu sendiri.

Menurut Posner (1987:342) nilai adalah: "General standards by which we formulate attitudes and beliefs and according to which we have ". Nilai adalah standar umum yang tercermin dalam tingkah laku sesuai keyakinan seseorang. Sistem nilai - nilai kepribadian dan profesi akuntansi dan kemampuan untuk membuktikan hasil kerjanya kepada masyarakat merupakan kesuksesan yang besar. Nilai kepribadian seorang harus termasuk akuntan dan auditor menjadi perhatian dalam menghasilkan keputusan akuntansi dan opini yang akurat bagi kepentingan masyarakat, terutama pengguna laporan keuangan. Nilai-nilai dalam pribadi seseorang mempengaruhi kemampuan manajerial dan strategi pengambilan keputusan termasuk tingkat profesionalisme dipengaruhi oleh nilainilai pribadi (personal values).

Nilai agama seharusnya menjadi kekuatan moral dan dinamika moral didalam kegiatan seseorang (Uygur, 2009: 205). Agama akan berpengaruh pada nilai dalam pekerjaan dan harapan pegawai yang tercermin dalam perilaku dan pendekatan yang dipilih (El-Kot, 2002:3). Masing-masing orang memiliki perangkat, nilai sekalipun tidak dapat diungkap secara eksplisit. Perilaku beretika diperlukan oleh masyarakat agar semuanya dapat berjalan secara teratur. Nilai-nilai dalam pekerjaan antara lain yaitu: kejujuran, integritas, mematuhi janji, loyalitas, keadilan, menghargai dan peduli terhadap orang lain, bertanggung jawab, memberikan yang terbaik, 
Akuntan harus bersikap independen dalam kenyataan dan penampilan, memenuhi standar teknis dan etika profesi, berusaha keras untuk terus meningkatkan kompetensi dan mutu jasa, dan melaksanakan tanggung jawab profesional dengan kemampuan terbaik. Akuntan harus memenuhi prinsip- prinsip prilaku profesional dalam menentukan lingkup dan sifat yang akan diberikan.

Etika sedikit banyak berbeda dengan moralitas. Moralitas itu sendiri adalah sesuatu sistem nilai tentang bagaimana kita harus hidup secara baik sebagai manusia. Bisa diartikan bahwa moralitas adalah sesuatu tradisi kepercavaan dalam agama dan kehudayaan, tentang perilaku yang baik dan yang buruk. Moralitas memberi manusia aturan atau petunjuk yang konkrit tentang bagaimana sikap manusia harus hidup, dan memberitahukan manusia untuk menghindari perilaku perilaku yang tidak baik. Etika dan moral sebenamnya saling terkait satu dengan yang lain karena etika pada akhimya menghimbau orang untuk bertindak sesuai dengan moralitas, tetapi bukan karena tindakan itu diperintahkan bahwa hal itu baik untuk pribadinya sendiri. Rafiki dan Wahab (2014) terdiri dari Kreativitas (Creativity), kejujuran (bonesty) dan kepercayaan (trust), pencapaian diri (personal fulfillment), komitmen (commitment), motivasi (motivation) dan kepuasan kerja (job satisfaction), komitmen organisasional (organisational commitment), pengembangan emosional (emotional development), kompetensi spiritual (Spiritual competence), bekerja secara lengkap dan paripurna (encouraged holistic ways of working), membangun komunitas (developed community at work), pemberdayaan (empowered the workforce and human society), pencegahan risiko dan etika (risk aversion and ethics), pengelolaan batin dan pengembangan karir (stress management and career development).

Sesuai Accounting and Auditing Organization for Islamic Financial Instituions (AAOIFI), (1998: 4-6), Dasar syariah akuntan dalam menjalankan tugas perofesionalnya meliputi Integrity, Vicegerency of Humanity, Sincerity, Piety, Righteousness and making one's work perfect, Allah fearing conduct in everything, Mens accountability before Allah. Prinsip atau nilai-nilai yang menjadi pedoman akuntan dalam menjalankan tugas profesionalnya adalah meliputi: 
a. Dapat dipercaya (trustworthiness), akuntan harus memiliki tingkat integritas dan kejujuran, kebenaran dan kebaikan yang tinggi, dapat menjaga kerahasiaan informasi yang diperoleh selama tugas profesional, selama menjalankan yang diketahuinya selama pelaksanaan tugas dan jasa baik kepada organisasi atau langganannya, serta tidak menyajikan kejadian dan informasi yang tidak senyatanya. Surat An Nissa ayat 58: "Sesunggubnya Allah menyuruh kamu menyampaikan amanat kepada yang berhak menerimanya, dan (menyuruh kamu) apabila menetapkan bukum di antara manusia supaya kamu menetapkan dengan adil. Sesunggubnya Allah memberi pengajaran yang sebaik-baiknya kepadamu. Sesunggubnya Allah adalah Maha mendengar lagi Maha melihat." Islam menjadikan integritas sebagai nilai tertinggi perilaku seorang muslim. Islam mensyaratkan kemampuan, kompetensi dan kualifikasi tertentu untuk melaksanakan suatu kewajiban. Dalam Al-Qur'an surat Al-Qashash ayat 26 disebutkan bahwa: "sesunggubnya orang yang paling baik yang kamu ambil untuk bekerja (pada kita) adalah orang yang kuat lagi dapat dipercaya". Seseorang dituntut untuk memiliki kepribadian yang dilandasi oleh sikap jujur, berani, bijaksana, dan bertanggung jawab untuk membangun kepercayaan agar dapat memberikan dasar yang kuat untuk pengambilan keputusan. Bersikap dan bertindak jujur merupakan tuntutan untuk dapat dipercaya. Hasil pekerjaan dengan integitas menjadikan dapat dipercaya oleh pengguna ketika karyawan menjunjung tinggi kejujuran dan didukung oleh sikap berani untuk menegakkan kebenaran.

b. Religious Legitimacy, Setiap kegiatan berkaitan tugas profesional akuntan harus memiliki dasar legitimasi atau memiliki dasar hukum sesuai syariah. Allah menyebutkan disurat at Talaq ayat 2: "...dan persaksikanlab dengan dua orang saksi yang adil di antara kamu dan hendaklah kamu tegakkan kesaksian itu karena Allah. Demikianlah diberi pengajaran dengan itu orang yang beriman kepada Allah dan hari akbirat. Barangsiapa bertakwa kepada Allah niscaya Dia akan mengadakan baginya jalan keluar". Ayat 3 di surat at Talaq juga disebutkan: "...Dan barangsiapa yang bertawakkal kepada Allah niscaya Allah 
akan mencukupkan (keperluan)nya. Sesunggubnya Allab melaksanakan urusan yang (dikehendaki)Nya. Sesunggubnya Allah telah mengadakan ketentuan bagi tiap-tiap sesuatu".

c. Objektivitas, Akuntan harus bertindak adil (fair), tidak memihak salah satu kelompok pemakai informasi akuntansi (netral), tidak bias baik dalam kenyataan maupun dalam penampilan. Akuntan dalam menggunakan professional judgement dan menjalankan tugasnya tidak ada hubungan subordinate dengan lainnya yang saling mempengaruhi. Dalam menjalankan tugasnya, auditor harus selalu mempertahankan sikap mental independen di dalam memberikan jasa profesionalnya. Selain itu auditor juga harus mempertahankan integritas dan objektivitas, harus bebas dari benturan kepentingan (conflict of tnterest) dan tidak boleh membiarkan faktor salah saji material (material misstatement) yang diketahuinya atau mengalihkan (mensubordinasikan) pertimbangannya kepada pihak lain. Disebutkan dalam surat an Nahl, ayat 90: "Sesungguhnya Allab menyurub (kamu) Berlaku adil dan berbuat kebajikan, memberi kepada kaum kerabat, dan Allab melarang dari perbuatan keji, kemungkaran dan permusuban. Dia memberi pengajaran kepadamu agar kamu dapat mengambil pelajaran". Al Maidah ayat 2 menyebutkan: "...dan janganlah sekali-kali kebencian(mu) kepada sesuatu kaum karena mereka menghalang-halangi kamu dari Masjidilharam, mendorongmu berbuat aniaya (kepada mereka). Dan tolong-menolonglab kamu dalam (mengerjakan) kebajikan dan takwa, dan jangan tolong-menolong dalam berbuat dosa dan pelanggaran. Dan bertakwalab kamu kepada Allah, sesunggubnya Allah amat berat siksa-Nya". Surat Al Imran ayat 199 menegaskan: "... mereka berendab hati kepada Allah dan mereka tidak menukarkan ayat-ayat Allah dengan harga yang sedikit. Mereka memperoleh pahala di sisi Tubannya. Sesunggubnya Allah amat cepat perhitungan-Nya".

d. Kompetensi dan ketekunan professional, Akuntan harus memiliki kompetensi professional dan pelatihan-pelatihan yang lengkap dalam menjalankan tugas atau jasa profesional yang memerlukan ketekunan dan ketepatan yang tinggi dalam rangka memenuhi tanggungjawabnya kepada Allah 
SWT, dirinya, sosial, profesi, atasan, dan klien. Allah sudah menyampaikan disurat Ali Imran ayat 102: "Hai orang-orang yang beriman, bertakwalah kepada Allah sebenar-benar takwa kepada-Nya; dan janganlab sekali-kali kamu mati melainkan dalam keadaan beragama Islam".

e. Perilaku yang didorong keimanan, Perilaku akuntan dalam menjalankan profesinyan harus konsisten dengan keimanan yaitu nilai islam yang berasal dari prinsip-prinsip dan aturanaturan syariah terutama berupa Alquran dan hadits. Alquran surat Al Baqarah ayat 30 disebutkan bahwa" Dialah Allah, yang menjadikan segala yang ada di bumi untuk kamu dan Dia berkehendak (menciptakan) langit, lalu dijadikan-Nya tujuh langit. Dan Dia Maha Mengetahui segala sesuatu". Sedangkan disurat Al Nisa ayat 1 juga disebutkan: "...Sesunggubnya Allah selalu menjaga dan mengawasi kamu".

f. Perilaku profesional dan standar teknis, Akuntan dalam menjalankan tugas dan jasa profesionalnya harus mengikuti setiap peraturan profesi, sesuai dengan standar akuntansi dan aturan-aturan lain terkait. Allah SWT menerangkan di surat Ali Imran ayat 104: "Dan hendaklah ada di antara kamu segolongan umat yang menyeru kepada kebajikan, menyurub kepada yang ma'ruf dan mencegah dari yang munkar, merekalah orang-orang yang beruntung". Surat al Zalzalah ayat 7 dan 8 menerangkan: "Barangsiapa yang mengerjakan kebaikan seberat dzarrahpun, niscaya dia akan melibat (balasan) nya"., "Dan barangsiapa yang mengerjakan kejahatan sebesar dzarrahpun, niscaya dia akan melihat (balasan)nyapula". Surat al Nisa ayat 86: "...Sesunggubnya Allah memperbitungankan segala sesuatu". Aspek dasar syariah meliputi religious legitimacy dan perilaku yang didorong keimanan (faith driven conduct). Aspek dasar profesi akuntansi meliputi perilaku profesional dan standar teknis sedangkan yang memenuhi kedua aspek sekaligus yaitu aspek syariah dan profesi akuntansi adalah sifat dapat dipercaya (trustworthiness), obyektifitas, kompetensi dan ketekunan profesional (professional competence and diligence). 


\section{Keputusan Akuntansi}

Pekerjaan akuntan selalui melekat dengan pilihan dan keputusan. keputusan (decision) berarti menentukan diantara pilihan (alternative choice). Keputusan adalah pemilihan diantara alternatif pilihan yang dicapai sesudah dilakukan pemikiran dan pertimbangan atas berbagai alternatif. Sebelum keputusan ditetapkan, didahului pertimbangan yang menyeluruh tentang kemungkinan dan konsekuensi yang bisa timbul. Allah SWT menerangkan disurat Al Nahl ayat 90: "Sesunggubnya Allab menyurub (kamu) berlaku adil dan berbuat kebajikan, memberi kepada kaum kerabat, dan Allah melarang dari perbuatan keji, kemungkaran dan permusuban. Dia memberi pengajaran kepadamu agar kamu dapat mengambil pelajaran". Surat al Taha ayat 7 menegaskan bahwa: "Dan jika kamu mengeraskan ucapanmu, maka sesunggubnya Dia mengetabui rahasia dan yang lebih tersembunyi".

Umumnya, penelitian tentang keputusan akuntansi menggunakan Teori Keagenan dan Teori perkembangan moral kognitif yang dikembangkan oleh Kohlberg (1969) untuk menjelaskan proses pengambilan keputusan dan memahami alasan seseorang didalam mengambil keputusan. Teori keagenan mengatakan bahwa perilaku manajemen laba terjadi karena didorong sifat oportunistik individu yang lebih mementingkan kepentingan pribadi dari sisi ekonomi. Teori keagenan belum mempertimbangkan etika sebagai dasar pengambilan keputusan (Nazaruddin, 2011:6). Penelitian ini menggunakan pertimbangan nilai Islam dalam pengambilan keputusan akuntan.

\section{Penelitian Relevan Terdahulu}

Penelitian tentang nilai-nilai Islam sudah dilakukan, Baharun (2000:20) menguji nilai keislaman yaitu jujur, amanah, adil dan ikhlas para pengusaha pada industri teknologi informasi. Hasilnya yaitu bahwa nilai agama secara statistik tidak ada korelasi signifikan terhadap kinerja para pengusaha industri teknologi informasi di Malaysia. Ahmed (1994: 15) hasil penelitiannya menyebutkan bahwa semua prinsip akuntansi yang bertujuan untuk memenuhi prinsip 
fairness dan justice dapat dilaksanakan pada perbankan Islam. Uygur (2002: 2) dalam penelitiannya bahwa nilai islam menjadikan rasionalitas para manajer dan pemilik usaha kecil dan menengah menjadi lebih rasional dan profesional khususnya setelah masa liberalisasi ekonomi tahun 1980an.

Ali (1988:582) dengan menggunakan 53 indikator nilai etika Islam dan 7 indikator nilai individu membuktikan bahwa nilai Islam memiliki korelasi dengan nilai individual untuk semua indikator. Raiya (2008:58-60) dalam penelitiannya mengembangkan the Psychological Measure of Islamic Religiousness (PMIR) dan memisahkan sampel muslim dan kristen yang hasilnya yaitu bahwa Islam mempunyai peran sentral dalam kehidupan seorang muslim. Salem dan Aqil (2012:74) dalam peniltiannya di perbankan Libya menghasilkan bahwa Nilai etika Islam individual menmpunyai efek positif terhadap affective commitment, continuance commitment dan normative commitment para pegawai.

Rokhman (2010: 24-25) menggunakan dengan 17 indikator nilai-nilai Islam dan hasil penelitiannya membuktikan bahwa etika kerja islam berpengaruh positif pada kepuasan kerja dan komitmen organisasi. Pimpinan perusahaan perlu mendukung dengan mengadakan kebijakan, program dan training secara memadai untuk menjamin bahwa setiap pegawai memahami dan menjalankan nilainilai Islam di tempat kerja. Fianto (2014:9) membuktikan bahwa perilaku pembelian dipengaruhi oleh nilai keagamaan yang diyakini seseorang. Perilaku seseorang dapat dipengaruhi oleh nilai-nilai agama diyakininya. Perilaku yang dapat timbul dari adanya behavioral beliefs, outcome beliefs dan normative beliefs serta motivasi untuk mematuhinya. Perilaku seseorang dipengaruhi oleh nilai-nilai agama juga dapat dipengaruhi oleh aspek kepercayaan seseorang terhadap perusahaan tempatnya bekerja. Ketika seseorang meyakini nilainilai agama tertentu dan perusahaan mampu memenuhi harapan mengenai nilai yang diyakininya maka seseorang akan melakukan tindakan yang bernilai bagi perusahaan. 


\section{Metode Penelitian}

Subjek penelitian adalah pegawai bagian akuntansi lembaga keuangan syariah yang berlokasi di Provinsi Daerah Istimewa Yogyakarta. Pemilihan lembaga keuangan syariah yang berlokasi di Provinsi Daerah Istimewa Yogyakarta sebagai sampel diangap cukup representatif. Data diperoleh dengan menyebarkan kuisoner kepada objek penelitian yaitu pegawai bagian akuntansi lembaga keuangan syariah berlatar belakang pendidikan akuntansi dan nonakuntansi.

Data diperoleh dengan menyebarkan kuesioner penelitian. Kuisioner yang terkumpul sebanyak 84 dari 200 yang disebarkan kepada pegawai bagian akuntansi yang bekerja di BMT, Bank Umum Syariah, Unit Usaha Syariah yang beroperasi di Provinsi Daerah Istimewa Yogyakarta dan yang kembali sebanyak 75 lembar. Pemilihan sampel responden adalah pegawai bagian akuntansi yang bekerja di BMT, Bank Umum Syariah, Unit Usaha Syariah karena dipastikan adalah beragama Islam sehingga nilai-nilai personal yang dipilih adalah nilai-nilai personal yang berlandaskan nilai dalam agama Islam.

Model penelitian ini adalah dapat digambarkan dalam formula sebagai berikut:

$$
\begin{array}{ll}
\text { KEP }=\mathrm{a}+\beta_{1} \mathrm{TRUST}+\beta_{2} \mathrm{LEG}+\beta_{3} \mathrm{OBJ}+\beta_{4} \mathrm{COMP}+\beta_{5} \mathrm{FAITH}+\beta_{6} \mathrm{PROF}+\mathrm{e} \\
\mathrm{A} & (+) \quad \text { konstanta } \quad(+) \quad(+) \quad(+) \\
\mathrm{KEP} & =\text { Keputusan Akuntansi } \\
\text { TRUST } & =\text { Dapat dipercaya (trustworthiness) } \\
\text { LEG } & =\text { Religious Legitimasi } \\
\text { OBJ } & =\text { Objektivitas } \\
\text { COMP } & =\text { professional competence and diligence } \\
\text { FAITH } & =\text { Faith driven conduct } \\
\text { PROF } & =\text { professional conduct and technical standards } \\
\mathrm{B} & =\text { Koefisien } \\
\mathrm{e} & =\text { error term }
\end{array}
$$


Variabel bebas dalam penelitian ini adalah nilai-nilai Islam dalam akuntansi yaitu Dapat dipercaya (trustworthiness), Religious Legitimacy, Obyektivitas, professional competence and diligence, Faith driven conduct, dan professional conduct and technical standards sedangkan variabel terikatnya adalah keputusan akuntansi Definisi Operasional Variabel sebagai berikut:

a. Dapat dipercaya (trustworthiness), Trustworthiness adalah nilai islam yang mengajarkan sifat dapat dipercaya, integritas, kebenaran, kejujuran dan ketulusan dalam menjalankan tugas profesional akuntan yang diukur empat pertanyaan.

b. Religious Legitimacy, Religous Legitimacy adalah nilai islam yang mensyaratkan akuntan dalam setiap kegiatan profesinya harus harus memiliki legitimasi syariah atau sesuai dengan hukum islam yang diukur dengan empat pertanyaan

c. Objectivity, Objectivity adalah nilai islam yang mensyaratkan akuntan supaya selalu bertindak adil, tidak memihak, bebas dari konflik kepentingan dalam kenyataan dan dalam penampilan yang diukur dengan lima pertanyaan

d. Professional competence and diligence, Professional competence and diligence adalah nilai islam yang mensyaratkan akuntan harus memiliki kompetensi professional dan sudah menempuh keahlian yang lengkap melalui berbagai pelatihan untuk penugasan yang memelukan ketekunan dan ketepatan akuntan yang diukur dengan lima pertanyaan

e. Perilaku yang didorong keimanan (faith driven conduct), Perilaku yang didorong keimanan (faith driven conduct) adalah nilai islam yang mengajarkan sesorang untuk konsisten dengan keyakinan akan nilai islam yang berasal dari prinsip dan aturan syariah yang diukur dengan delapan pertanyaan

f. Perilaku professional dan standar teknik, Perilaku professional dan standar teknik adalah nilai Islam yang menuntunkan akuntan untk menjalakan tugas profesionalnya dengan selalu mematuhi peraturan profesi yaitu standar akuntansi dan pedoman lainnya yang diukur dengan empat pertanyaan. 
g. Keputusan akuntansi, Keputusan akuntansi adalah pilihan atas berbagai alternatif pilihan setelah mempertimbangkan berbagai faktor termasuk konsekuensinya setiap alternatif pilihan.

Instrumen penelitian berupa daftar pertanyaan disusun dan dikembangkan terutama berasal dari kode etik akuntan lembaga keuangan syariah yang diterbitkan oleh AAOIFI (1998) dan beberapa penelitian terdahulu untuk memperkuat yaitu penelitian Ali (1988), Rafiki dan Wahab (2014) Untuk variabel Islamic value, sedangkan Keputusan Akuntansi disusun dan dikembangkan dengan memberikan kasus untuk mendapatkan gambaran keputusan pegawai bagian akuntansi yaitu dari penelitian Nazaruddin (2011).

Metode pertanyaaan di kuesioner ini adalah pertanyaan tertutup dengan altematif pendapat yang menggunakan skala likert dengan rentang jawaban - 1 yang berarti nilai tersebut bertentangan dengan kepribadian responden hingga 7 yang berarti nilai tersebut merupakan nilai yang paling penting sebagai penuntun dalam kehidupan responden dengan memberikan tempat untuk menuliskan tambahan informasi kualitatif tambahan yang ingin disampaikan oleh responden. Rentang Nilai yang digunakan dalam penelitian ini yaitu:

-1 Bertentangan dengan nilai dalan diri saya

$0 \quad$ Sangat tidak penting

1 Tidak penting

$2 \quad$ Kurang penting

$3 \quad$ Sedikit penting

$4 \quad$ Penting

$5 \quad$ Lebih penting

$6 \quad$ Yang paling penting

Semua jawaban dari responden diproses dengan menggunakan perangkat lunak SPSS for Windows. 


\section{Analisis}

Uji validitas menggunakan uji Pearson hasilnya menunjukkan bahwa setiap pertanyaan memiliki nilai signifikansi 0,00 atau kurang 0,05 dan memiliki nilai korelasi semua pertanyaan lebih dari 0,3 dengan rata-rata adalah 0,583 . Hasil uji validitas untuk semua menunjukkan bahwa kedua instrumen tersebut merupakan instrumen yang valid dalam mengukur setiap variabel. Hasil Uji Reliabilitas ditunjukkan nilai cronbach alpha setiap variabel $>0,6$ dengan nilai rata-rata 0 , 748. Hasil Uji Asumsi Klasik yang dilakukan meliputi uji normalitas, autokorelasi, multikolinieritas dan heteroskedastisitas. Hasil uji normalitas menggunakan uji Kolmogorov-Smirnov diketahui hasilnya adalah 0,541 dengan tingkat signifikansi sebesar 0,655. Hal ini berarti bahwa data residual berdistribusi normal. Hasil uji autokorelasi yang digunakan adalah uji Durbin-Watson.

Hasil uji statistik menunjukkan bahwa nilai e adalah 0,384 dan menunjukkan bahwa tidak ada autokorelasi. Nilai tolerance hasil uji multikolinieritas dengan untuk masing-masing variabel semuanya diatas 0,10 dengan nilai rata-rata 0,7955 yang berarti tidak ada multikolinieritas antar variabel independen dalam model regresi. Uji heteroskedastisitas bertujuan menguji apakah dalam model. Berdasarkan scatterplot terlihat bahwa titik-titik menyebar secara acak tidak berkumpul pada satu titik saja.

\section{Tabel 1.}

\section{Demografi Responden Berdasarkan Jurusan}

\begin{tabular}{lcc}
\hline Pendidikan & Jumlah responden & $\%$ \\
Akuntansi & 34 & $45 \%$ \\
Nonakuntansi & 41 & $54 \%$ \\
Lumlah & 75 & $100 \%$ \\
\hline
\end{tabular}

Responden sebagian besar adalah pegawai berlatarbelakang pendidikan jurusan akuntansi (45\%). Untuk responden berlatarbelakang pendidikan jurusan nonakuntansi (54\%). Responden juga dibedakan berdasarkan ienis kelamin pada pria dan wanita, dan tersaji pada tabel 2 
Tabel 2.

Demografi Responden Berdasarkan Jenis Kelamin

\begin{tabular}{llc}
\hline Jenis & kelamin & Jumlah responden \\
\hline Pria & 32 & $42 \%$ \\
Wanita & 43 & $57 \%$ \\
Jumlah & 75 & \\
\hline
\end{tabular}

Dalam penelitian ini responden didominasi oleh pegawai wanita (57\%) berjumlah 43 responden, sedangkan responden pria berjumlah 32 orang (42\%). Dilihat dari persentase yang diperoleh, hasil tersebut mencerminkan tingginya minat seluruh responden pegawai bagian akuntansi untuk berpartisipasi dalam penelitian nilai-nilai-nilai Islam (personal values). Analisis terhadap hasil pengujian regresi berganda sebagai berikut:

Tabel 3

Hasil Uji Statistik

\begin{tabular}{llll}
\hline Variabel & $\boldsymbol{\beta}$ & thitung & Signifikansi \\
\hline TRUST & 0,025 & 0,277 & 0,645 \\
LEG & 0,314 & 1,716 & $0,009^{*}$ \\
OBJ & 0,083 & 0,553 & 0,418 \\
COMP & 0,075 & 2,105 & $0,048^{*}$ \\
FAITH & 0,168 & 2,155 & $0,035^{*}$ \\
PROF & 1,713 & 3,573 & $0,044^{*}$ \\
\hline \multicolumn{5}{c}{$*$ tingkat signifikansi $5 \%$}
\end{tabular}

Dapat dipercaya (trustworthiness)

Berdasarkan hasil uji t, pengaruh nilai islam Dapat dipercaya (trustworthiness) terhadap keputusan akuntansi diperoleh $\beta$ sebesar 0,025 , t hitung sebesar 0,277 dengan nilai sig. 0,645, nilai sig. 0,645 lebih besar dari 0,05 sehingga hasil ini menunjukkan bahwa tidak ada pengaruh positif yang signifikan antara nilai Islam Dapat dipercaya (trustworthiness) terhadap keputusan akuntansi. tingkat keyakinan terhadap suatu nilai bersinggungan erat dengan nilai global (Fianto, 2014:8) ada kemungkinan bahwa nilai yang diyakini seseorang berkaitan tidak selamanya konstan sangat dipengauhi 
oleh lingkungan eksternal baik di perusahaan, regulasi dan internal akuntan.

\section{Religous Legitimacy}

Berdasarkan hasil uji t, pengaruh nilai islam religous legitimacy terhadap keputusan akuntansi diperoleh $\beta$ sebesar 0,314 , t bitung sebesar 1,716 dengan nilai sig. 0,009 nilai sig. 0,009 lebih kecil dari 0,05 sehingga hasil ini menunjukkan bahwa ada pengaruh positif yang signifikan antara nilai Islam berupa religous legitimacy terhadap keputusan akuntansi. Islam memandang bahwa kegiatan ekonomi (bekerja) termasuk kegiatan akuntansi merupakan kewajiban agama (Parboteeah, 2009: 62). Nilai Islam konsisten dengan nilai kemanusian dan mencakup semua aspek kehidupan dan keilmuan (Al Aidaros et al., 2013: 12) termasuk akuntansi

\section{Objectivity}

Berdasarkan hasil uji t, pengaruh nilai islam Objectivity terhadap keputusan akuntansi diperoleh $\beta$ sebesar 0,083, t hitung sebesar 0,553 dengan nilai sig. 0,418 nilai sig. 0,418 lebih besar dari 0,05 sehingga hasil ini menunjukkan bahwa tidak ada pengaruh positif yang signifikan antara nilai Islam berupa Objectivity terhadap keputusan akuntansi. Banyak alasan yang mempengaruhi independensi akuntan. Peraturan dan sistem politik terkadang memberikan kelaluasaan untuk melakukan tindakan-tindakan yang tidak etis, hal tersebut menyebabkan keputusan akuntansi menjadi bias (Moore,2004). informasi akuntansi sebagai hasil keputusan penyusun informasi dipengaruhi juga oleh subyekstivitas subyektivitas penyajinya, sehingga kewajaran informasi akuntansi tidaklah bebas nilai. Fleksibititas pemilihan metode seringkali dipergunakan oleh penyaji laporan Keuangan untuk melakukan tindakan creative accounting (Sulistiawan, 2009: 32). 
Kompetensi dan ketekunan profesional (professional competence and diligence)

Berdasarkan hasil uji t, pengaruh nilai islam professional competence and diligence terhadap keputusan akuntansi diperoleh $\beta$ sebesar 0,075, t bitung sebesar 2,105 dengan nilai sig. 0,048, nilai sig. 0,048 lebih kecil dari 0,05 sehingga hasil ini menunjukkan bahwa ada pengaruh positif yang signifikan antara nilai Islam professional competence and diligence terhadap keputusan akuntansi. Dalam pengambilan keputusan akuntansi terkait informasi yang harus disajikan, pegawai bagian akuntansi didorong oleh faktor lain, kompetensi dan ketekunan dalam pekerjaan bukanlah menjadi pertimbangan pokok. Hal ini membuktikan bahwa keputusan seseorang adalah multi dimensi meskipun Islam menempatkan integritas sebagai nilai tertinggi yang memandu seluruh perilakunya dan Islam juga menilai perlunya kemampuan, kompetensi dan kualifikasi tertentu untuk melaksanakan suatu pekerjaan. Hasil penelitian terhadap pegawai bagian akuntansi terkait keputusan yang diambil sudah selaras dengan penelitian Fearnley, S. and Beattie, V. and Brandt, R., (2005) bahwa proses pengambilan keputusan akuntansi seperti juga audit adalah proses yang tidak teramati. Hanya pihak yang terlibat dalam proses, yaitu akuntan dan manajemen perusahaan yang tahu bagaimana keputusan akuntansi diambil dan pertimbangannya tercapai.

\section{Perilaku yang didorong keimanan (faith driven conduct)}

Berdasarkan hasil uji t, pengaruh nilai islam Perilaku yang didorong keimanan (faith driven conduct) terhadap keputusan akuntansi diperoleh $\beta$ sebesar 0,168, t hitung sebesar 2,155 dengan nilai sig. 0,035, nilai sig. 0,035 lebih kecil dari 0,05 sehingga hasil ini menunjukkan bahwa ada pengaruh positif yang signifikan antara nilai Islam Perilaku yang didorong keimanan (faith driven conduct) terhadap keputusan akuntansi. Keputusan dan kebijakan akuntansi terkait informasi keuangan seperti manajemen laba tidak hanya dapat dijelaskan dengan teori keagenan saja, tetapi secara empiris bisa dijelaskan pula dengan menggunakan teori lain. Dengan kata lain pengambilan kebijakan etis dipengaruhi oleh kemampuan 
individu (Nazaruddin, 2011). Perilaku seseorang dapat dipegaruhi oleh nilai agama yang diyakininya (Fianto, 2012:9).

\section{Professional conduct and technical standards}

Berdasarkan hasil uji t, pengaruh nilai islam Professional conduct and technical standards terhadap keputusan akuntansi diperoleh $\beta$ sebesar 1,713 , t hitung sebesar 3,573 dengan nilai sig. 0,044, nilai sig. 0,044 lebih kecil dari 0,05 sehingga hasil ini menunjukkan bahwa ada pengaruh positif yang signifikan antara nilai Islam professional conduct and technical standards terhadap keputusan akuntansi. Pegawai kurang menyukai melakukan kolusi untuk melakukan fraudulent behaviour seperti mencuri ketika gaji relatif tinggi (Chen dan Sandino, 2011:33). Lingkungan mempengaruhi keputusan dalam pelaporan keuangan Sulistyawan, 2009: 33).

\section{Kesimpulan}

Keputusan akuntansi ditentukan oleh berbagai faktor tergantung tingkat nilai seseorang yang berbeda-beda. Hasil pengujian menunjukkan bahwa religious legitimacy, professional competence and diligence, faith driven conduct, professional conduct and technical standards berpengaruh secara signifikan terhadap keputusan akuntansi. Namun variabel trustworthiness, dan objectivity tidak mempengaruhi secara signifikan terhadap keputusan akuntansi.

Sebaiknya instrumen penelitian tentang nilai-nilai yang bersifat intrinsik perlu mengikuti perkembangan dinamika ilmu akuntansi tentang nilai-nilai dalam ilmu akuntansi baik tingkat individu dan eksternal. Pendekatan kualitatif perlu dilakukan untuk mendapatkan gambaran yang lebih mendalam dan lebih lengkap. 


\section{Daftar Pustaka}

Adebayo, R. Ibrahim dan Hassan M. Kabir. 2013. Ethical Principles of Islamic Financial Institutions. Journal of Economic Cooperation and Development, Vol. 34, No. 1: 63-90

Ahmed, Eltegani A. 1994. Accounting Postulates and Principles from an Islamic Perspective. Review of Islamic Economics, Vo1.3, No.2, (1994), pp. 1-18

Al-Aidaros, Al-Hasan, et al., 2013. Ethics and Ethical Theories from an Islamic Perspective. International Journal of Islamic Thought Vol. 4: (Dec.): 1-13

Ali, Abbas. 1988. Scalling in Islamic Work Ethic. The Journal of Social Psychology, Vol. 128, No. 5: 575-583

Baharun, Rohaizat. 2000. The Effect of the Islamic Values of Enterpreurs in Information Technology Industry. Universiti Tekonologi Malaysia, Laporan Penelitian, Research Vote No. 71335: 1-25

Barbara Ann White, 2005. Economic Efficiency and The Parameter of Fairness: A Marriage of Marketplace Morals and The Ethic of Care, Cornell Journal of Law and Public Policy, Vol. 15, No. 1:1-72

Chen, Clara X. dan Sandino, Tatiana. 2011. Can Wages Buy Honesty? The Relationship between Relative Wages and Employee Theft. The 2011 International Symposium on Management Accounting: 1-51

Christopher J. Robertson _ Jamal A. Al-Khatib _ Mohammed AlHabib. 2002. The Relationship between Arab Values and Work Beliefs: An Exploratory Examination. Thunderbird International Business Review, Vol. 44(5): 583-601

El-Kot, Ghada. 2002. An Exploratory Investigation of Some Work Related Values Among Middle Managers in Egypt. International Applied Business Research Conference. Puerto Vallarta, Mexico: 1-10 
Fearnley, S. and Beattie, V. and Brandt, R. 2005. Auditor independence and audit risk: a reconceptualisation. Journal of International Accounting Research, Vol. 4, No. 1: 39-71.

Fianto, Ahmad Y. A., et al. 2014. Development and Measurement of Islamic Values in Consumer Behaviour Research. International Journal of Business and Management Invention, Vol. 3, No. 9: $1-10$

Finegan, Joan. 1994. The Impact of Personal Values on Judgements of Ethical Behaviour in The Work Place. Journal of Business Ethics, Vol. 13:747-755.

Fraedrich, Ferrell. 2011. Ethical Decision Making for Business. 8th edition, Cengage Learning.

Fritzsche, David J. 1995. A Model of Decision Making Incorporating Ethical Values. Journal of Business Ethics, No. 12: 841-852.

Huber, Stefan dan Huber, Odilo W. 2012. "The Centrality of Religiosity Scale (CRS)". Religions, Ed. 3: 710-724.

John E. Fetzer Institute. 1999. Multidimensional Measurement of Religiousness/Spirituality for Use in Health Research. A Report of the Fetzer Institute/National Institute on Aging Working Group. West KL Avenue: 1-96

Jong, Eelke de, 2008. Religious Values and Economic Growth: A review and assessment of recent studies. NiCE Working Paper 08-111, Nijmegen Center for Economics (NiCE) Institute for Management Research Radboud University Nijmegen. http:// www.ru.nl/nice/workingpapers

Kohlberg, L. 1969. Stage and Sequence: The Cognitive-Developmental Approach to Socialization. in D. Goslin (ed.), Handbook of Socialization Theory and Research (Rand McNally, Chicage, IL): $347-480$

Marquette, Heather. 2010. Corruption, Religion and Moral Development. Religions and Development Research Programme, Working Paper 42: 1-38

Moore, Don A. et al., 2004. Conflicts of Interest and the Case of 
Auditor Independence: Moral Seduction and Strategic Issue Cycling. HBS Working Paper 03-115 Rev. 12/04

Nazaruddin, Ietje. 2011. Dampak Religiositas, Relativisme dan Idealisme Terhadap Penalaran Moral dan Perilaku Manajemen Laba. Disertasi, Universitas Diponegoro Semarang: 1-193

Omar, Syed Omar dan Agil, Syed. 2012. The Effects of Islamic Individuals' Ethics on Organizational Commitment of Employees in Libyan Public. Vol. 15, No. 1:21-28

Parboteeah, K. Praveen et al., 2009. Religious Groups and Work Values: A Focus on Buddhism, Christianity, Hinduism, and Islam. International Journal of Cross Cultural Management, Vol 9, No. 1: 51-67

Posner Barry Z. dan Warren H. Schmidt. 1993. Value Congruence and Diffrences between the Interplay of Personal Values and Organizational Value System. Journal of Business Ethics, No.12:341-347.

Rafiki, Ahmad dan Abdul Wahab, Kalsom. 2014. Islamic Values and Principles in the Organization: A Review of Literature. Asian Social Science; Vol. 10, No. 9: 2014: 1-7.

Rafiki, dan Kalsom, A. Wahab, 2014. Islamic Values and Principles in the Organization: A Review of Literature, Asian Social Science; Vol. 10, No. 9: 1-7.

Raiya, Hisham A. 2008. A Psychological Measure of Islamic Religiousness: Evidence for Relevance, Reliability and Validity. Dissertation, the Graduate College of Bowling Green State University: 1-160

Rice, Gillian dan Al-Mossawi, Mohammed. 2002. The Implications of Islam for Advertising Messages: The Middle Eastern Context. Journal of Euromarketing, Vol. 11, No. 3: 1-16.

Rokhman, Wahibur. 2010. The Effect of Islamic Work Ethics on Work Outcomes. EJBO Electronic Journal of Business Ethics and Organization Studies 
Sulistiawan, Dedhy. 2009. Studi Eksperimen tentang Dampak Konflik Kepentingan Terhadap Kebijakan Akuntansi. Jurnal Akuntansi \& Manajemen Vol. 4, No. 2: 31-40

Tozzi, Piero A. 2008. The Blessing or The Curse: Whose Values Will Guide Us? Where Will They Lead Us? Journal of Catholic Legal Studies, No. 47:167.

Tsalikis, J. dan M. Ortiz-Buanafina. 1990. Ethical Beliefs' Differences of Males and Females. Journal of Business Ethics, No. 9:509517.

Uygur, Selçuk. 2009. "The Influence of Religion over Work Ethic Values: The Case of Islam and Turkish SME Owner-Managers". Brunel Business School, Brunel University. Disertasi: 1-257 